\title{
THE BACTERIOLOGY OF ULCER OF THE STOMACH AND DUODENUM IN MAN *
}

\author{
Edward C. Rosenow and A. H. SANFORD
}

(From the Memorial Institute for Infections Diseases, Chicago, and the Mayo Clinic, Rochester, Minnesota)

\section{(WITH PLATES 4 AND 5)}

It is recognized that hemorrhage of the stomach with or without visible ulceration occurs rather commonly during the late stages of severe streptococcal infections in man and animals. The cause of the gastric lesions in these cases usually is thought to be the profound toxemia, in spite of the fact that many observers have demonstrated the presence of streptococci or diplococci in the lesions in the mucous membrane. The cause of the usual ulcer of the stomach in man, which tends to persist and which occurs commonly in otherwise healthy individuals, the usual symptoms or other evidences of infection being slight or wholly absent, is not clearly established. The presence of pyorrhea, as noted by Bolton ${ }^{1}$ and others, of blind abscesses about the roots of teeth, of chronically infected tonsils and sinuses about the head; the occurrence of acute attacks of such infections, especially streptococcal, of ten a week or ten days previous to acute ulceration and previous to exacerbation of symptoms in chronic ulcer; the aggravation of symptoms in chronic duodenal ulcer during the months when throat and other streptococcal infections are particularly prevalent, as emphasized by Moynihan ${ }^{2}$; the improvement in symptoms following eradication of foci of infection, as noted especially by Billings; ${ }^{3}$ and the fact that streptococci when of a certain grade of virulence, quite irrespective of their original source, are prone to localize in the mucous membrane of the stomach and duodenum of animals following intravenous injection, producing ulcers which resemble those in man, as shown by Rosenow ${ }^{4}$-all suggest strongly that a localized streptococcal infection may be an important factor in the original production of the ulceration.

* Received for publication May 12, 1915.

1. Ulcer of Stomach, 1913.

2. Duodenal Ulcer, 1913.

3. Jour. Am. Med. Assn,, 1914, 63, p. 399.

4. Jour. Am. Med. Assn,, 1913, 61, p. 1947. 
Heretofore, the cultures of ulcers of the stomach have been made chiefly after death and from the floor of the ulcer, and not usually from the emulsified tissues remote from the ulcerated area. The results, as should be expected, have been so unsatisfactory as to lead to a general belief that bacteriologic examination of ulcers as they occur in man cannot be made with any degree of satisfaction. However, a systematic bacteriologic study of the emulsified tissues surrounding the ulceration, removed during life at operation, should yield more trustworthy results.

In this paper, we wish to record the results of cultures and of the histologic examination of the tissues in a series of ulcers and lymph glands draining the ulcers, excised at operation. We wish here to express our appreciation of the opportunity afforded us in the willing co-operation of Dr. W. J. Mayo, Dr. C. H. Mayo, Dr. E. S. Judd, Dr. D. C. Balfour, Dr. A. J. Ochsner, Dr. A. D. Bevan, Dr. L. L. McArthur and Dr. C. H. McKenna.

\section{TECHNIC}

The ulcers and other tissues were excised under strictly aseptic precautions, covered at once with sterile gauze, and cultures made as soon as possible thereafter, usually within one to three hours. After some of the material from the floor of the ulcer, in suitable cases, had been withdrawn into a sterile pipette (for control cultures) and the surface of the ulcer thoroughly washed in running, sterile water, approximately one-half of the ulcer was excised with a small, sterile scalpel, the incisions being made from the normal tissue toward the center of the ulcerated area. The excised part was again washed thoroughly in sterile water or salt solution and the emulsion prepared in the sterile air chamber directly if the size of the tissue was small, or after the surface had been sterilized with passing through a very hot Bunsen flame or with a searing blade, if the piece of tissue was large enough. Cultures were made in some instances in the same way from the adjacent normal wall and in a number of instances from the indurated area far removed from the ulcerated surface and from the overlying mucous membrane. The lymph glands and other tissues were treated in a similar manner.

The emulsions were prepared in dextrose broth or $\mathrm{NaCl}$ solution, and the cultures made chiefly in tall columns $(9-12 \mathrm{~cm}$.) of dextrose agar and broth, with and without the addition of sterile ascites fluid, and on Loeffler's blood serum and ascites agar slants, as described by Rosenow.

The portion of the ulcer saved for microscopic study was fixed in alcohol or 10 percent formalin, imbedded in paraffin, stained with hematoxylin and eosin and for bacteria by the Gram-Weigert method. In this method complete decolorization was not practiced, because it was found that streptococci present were very easily decolorized; hence decolorization was carried to a pale blue only.

5. Jour. Am. Med. Assn., 1914, 63, p. 903. 
Cultures have been made from ulcers or regional lymph glands or from both in thirty-two cases. In fifteen the ulcer was situated in the pyloric end of the stomach, in five at the lesser curvature, in three in the fundus, and in twelve in the duodenum. In three cases there were both ulcer of the stomach and duodenum. Chronic appendicitis was associated with ulcer in seven of the cases, cholecystitis in five, and pancreatitis in three. Appendicitis, ulcer, and cholecystitis coexisted in two cases; ulcer, cholecystitis, and pancreatitis in one case. The age of the patients ranged from twenty to seventy-two years. The duration of the symptoms of ulcer at the time of operation ranged from six months to twenty-three years.

Cultures were made from the wall of ulcers in twenty-four cases. In these, streptococci were isolated in varying numbers (1-5000 colonies) in pure culture from nine ulcers, and in mixtures in all but one of the remaining fifteen. If judged by the numbers of streptococci found in the portion of the ulcers sectioned, it is certain that the number of colonies obtained in the cultures did not represent the actual number present; either some were dead to begin with, or from long residence in the tissue failed to grow in the new environment, or many were killed in the sterilization of the surface. In two cases of duodenal ulcer (one and twelve years old,) in which the ulcers were so situated as to make their total removal impossible, the usual streptococcus was isolated from a thin layer of the inflamed peritoneum directly over the ulcer, and in one from the hyperemic parietal peritoneum directly opposite the ulcer (Cases 112, 134). In the former, diplococci were demonstrated in the tissue (Fig. 8). In the latter, this was not attempted. Non-hemolysing staphylococci were isolated from ten cases, but never in pure form. Staphylococcus aurets was found in one ulcer, but not in pure form (Case 902). Bacillus welchii, in small numbers, was found in the ulcers or glands in four cases. They developed only in those tubes containing a large amount of the emulsion. A gram-positive bacillus, probably belonging to the subtilis group, was found in six cases, and a large, unidentified, gram-negative bacillus in three. The colon bacillus was found in rather large numbers in two cases after death, and in small numbers in a duodenal ulcer in one case during life. Yeast cells were isolated in large numbers from three ulcers, and in small numbers from one. A few sarcinae were grown in one case, and diphtheroid bacilli in three cases. 
TABLE 1

Summary of Facts and Results of Cultures in Gastroduodenal Ulcer

\begin{tabular}{|c|c|c|c|c|}
\hline Case & $\begin{array}{l}\text { Sex and } \\
\text { Age }\end{array}$ & $\begin{array}{l}\text { Probable Age } \\
\text { of Ulcer }\end{array}$ & $\begin{array}{c}\text { Location and Character } \\
\text { of Ulcer }\end{array}$ & Result of Cultures \\
\hline 1 & F., 25 & 3 years & $\begin{array}{l}\text { Puckered ulcer of duodenum } \\
2 \mathrm{~cm} \text {. from the pylorus }(0.5\end{array}$ & $\begin{array}{l}100 \text { colonies of streptococci; a few } \\
\text { staphylococci }\end{array}$ \\
\hline 2 & F., 40 & 10 years & $\begin{array}{l}\text { Constricted ulcer, anterior su- } \\
\text { perior wall, } 2 \mathrm{~cm} \text {. above py- } \\
\text { loric ring, } 0.5 \mathrm{~cm} \text {. in diam- } \\
\text { eter with clean base and in- }\end{array}$ & $\begin{array}{l}\text { A few colonies of large, gram-stain- } \\
\text { ing bacilli and staphylococci, and } \\
280 \text { colonies of streptococci }\end{array}$ \\
\hline $\mathbf{B}$ & F., 28 & 5 years & $\begin{array}{l}\text { Ulcer of stomach causing hour } \\
\text { glass constriction }\end{array}$ & Moderate number of streptococci \\
\hline $\mathrm{D}$ & M., 41 & 15 years & $\begin{array}{l}\text { Indurated, puckered, deep ul- } \\
\text { cer of pyloric ring }\end{array}$ & $\begin{array}{l}\text { Many colonies of yeast, gram-nega- } \\
\text { tive bacilli, streptococci, and } \\
\text { staphylococci }\end{array}$ \\
\hline $\mathbf{E}$ & $\ldots \ldots \ldots \ldots$ & $\ldots \ldots \ldots \ldots$ & Indurated ulcer of stomach.. & $\begin{array}{l}\text { Streptococci and a few staphylo. } \\
\text { cocci, and a large gram-negative } \\
\text { bacillus }\end{array}$ \\
\hline $\mathbf{F}$ & F., 26 & 6 weeks & $\begin{array}{l}\text { Ulcer of duodenum } 2 \mathrm{~cm} \text {. be- } \\
\text { yond pyloric ring }\end{array}$ & $\begin{array}{l}200 \text { colonies of streptococci; a few } \\
\text { colonies of staphylococci and } \\
\text { saprophytic bacilli }\end{array}$ \\
\hline $\mathbf{J}$ & M., 54 & 6 years & $\begin{array}{l}\text { Indurated ulcers in stomach } \\
\text { and duodenum }\end{array}$ & Pure culture of streptococci \\
\hline 2399 & 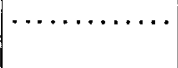 & $\ldots \ldots \ldots \ldots$ & Indurated ulcer of pylorus... & $\begin{array}{l}\text { Streptococci, staphylococci, and } \\
\text { large number of colon bacilli } \\
\text { (cultures made after death) }\end{array}$ \\
\hline 773 & M., 53 & 3 years & $\begin{array}{l}\text { Indurated duodenal ulcer ad. } \\
\text { herent to gall-bladder }\end{array}$ & $\begin{array}{l}1500 \text { colonies of staphylococci, and } \\
20 \text { colonies of streptococci }\end{array}$ \\
\hline 779 & F., 43 & 12 years & $\begin{array}{l}\text { Indurated healing ulcer of } \\
\text { duodenum }\end{array}$ & 180 colonies of staphylococci; 8 \\
\hline 849 & M., 26 & 7 years & Indurated uicer of duodenum & One colony of streptococci from \\
\hline 860 & M., 50 & & $\begin{array}{l}\text { A number of hard scars in } \\
\text { pylorus and duodenum. In- } \\
\text { durated undermined ulcer of }\end{array}$ & $\begin{array}{l}\text { gland draining ulcer } \\
\text { Pure culture of streptococci from } \\
\text { depths of ulcer; gland sterile }\end{array}$ \\
\hline 870 & M., 65 & 3 months & $\begin{array}{l}\text { Large, markedly indurated ul- } \\
\text { cer, extending half way } \\
\text { around pylorus }\end{array}$ & $\begin{array}{l}\text { Staphylococci, streptococci, and a } \\
\text { few colonies of Bacillus Welchii }\end{array}$ \\
\hline 885 & & 3 weeks & $\begin{array}{l}\text { Acute perforating ulcer of } \\
\text { stomach }\end{array}$ & $\begin{array}{l}5000 \text { colonies of a distinct, green. } \\
\text { producing streptococcus in pure } \\
\text { culture }\end{array}$ \\
\hline 886 & M., 46 & 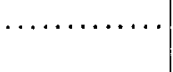 & Chronic ulcer of stomach..... & $\begin{array}{l}\text { Lymph gland cultured: two col- } \\
\text { onies of streptococci, and ten of } \\
\text { Bacillus Welchii }\end{array}$ \\
\hline 893 & M., 47 & 12 years & $\begin{array}{l}\text { Indurated ulcer of duodenum } \\
(2.5 \mathrm{~cm} .) \text {, perforated into } \\
\text { head of pancreas }\end{array}$ & $\begin{array}{l}2000 \text { colonies of yeast, and a few } \\
\text { sarcinae and streptococci from } \\
\text { ulcer; from gland, streptococci } \\
\text { only, adjacent normal mucous } \\
\text { membrane sterile }\end{array}$ \\
\hline 902 & M., 51 & 4 years & $\begin{array}{l}\text { Very large, markedly indurated, } \\
\text { crater-like ulcer of pylorus } \\
(2 \times 2.5 \mathrm{~cm} .)\end{array}$ & $\begin{array}{l}340 \text { colonies streptococci, } 120 \text { col- } \\
\text { onies Staphylococcus aureus, and } \\
50 \text { colonies of a diphtheroid ba- } \\
\text { cillus }\end{array}$ \\
\hline 904 & F., 20 & A few days & $\begin{array}{l}\text { Small, numerous, punctate ul- } \\
\text { cers of stomach, chiefly of } \\
\text { fundus }\end{array}$ & $\begin{array}{l}\text { Large number of green-producing } \\
\text { streptococci with marked involu- } \\
\text { tion forms, a few staphylococi } \\
\text { and colon bacilli (cultures made } \\
\text { six hours after death) }\end{array}$ \\
\hline 909 & F., 42 & & Ulcer of stomach........ & Cultures of gland from pylorus \\
\hline 947 & $\ldots \ldots \ldots$ & 6 months & Adherent ulcer of duodenum & $\begin{array}{l}\text { remained sterile } \\
\text { Gland shows approximately } 4200 \\
\text { colonies of green-producing strep- }\end{array}$ \\
\hline 31 & $F$ & Many years & $\begin{array}{l}\text { Markedly indurated ulcer of } \\
\text { pylorus, margin abrupt, hard, } \\
\text { and crater-like }(3 \dddot{\times} 2.5 \mathrm{~cm} .)\end{array}$ & $\begin{array}{l}\text { Streptococcus viridans, gram-posi- } \\
\text { tive and negative bacilli, and } \\
\text { staphylococci from floor of ulcer; } \\
\text { streptococci from depths of indu- } \\
\text { rated wall and from adjacert } \\
\text { lymoh gland }\end{array}$ \\
\hline
\end{tabular}


TABLE 1-Continued

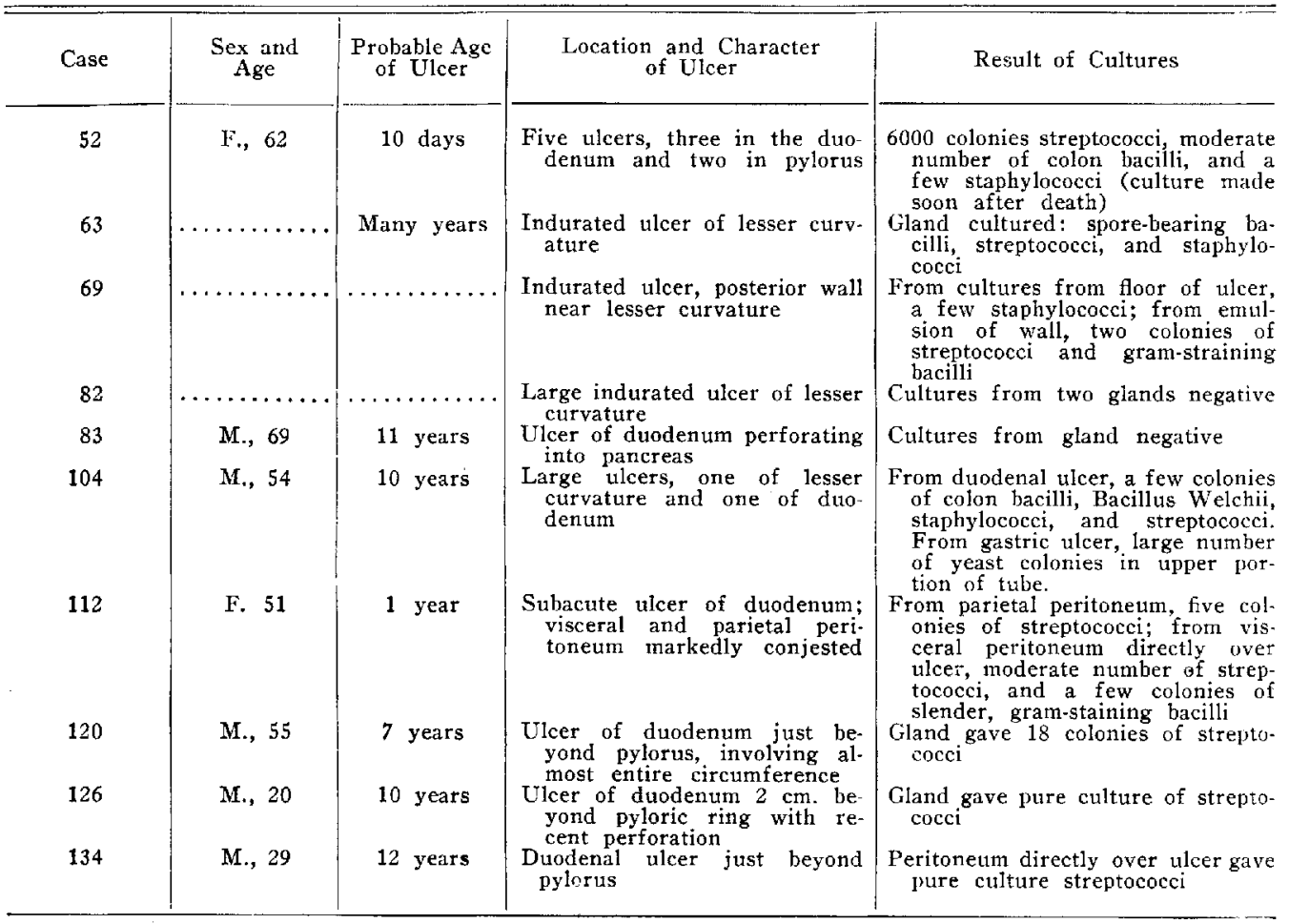

The results of the cultures in the broth were usually the same as those in tive agar, altho in some instances the former were positive when the latter were negative. The anaerobic cultures on blood agar and Loeffer's serum slants were nearly always sterile. A number of times marked odor-producing bacilli were isolated but these were not identified.

Lymph glands, varying in size from 0.5 to $1.5 \mathrm{~cm}$. in diameter, draining the ulcers, were cultured in eleven cases. Of these, five appeared to be sterile, four yielded streptococci in pure culture, two streptococci together with a few colonies of Bacillus welchii. Colon bacilli were not found in any of the glands. The glands which proved sterile were all from cases of ulcer of long standing in which no exacerbation of symptoms occurred shortly before surgical intervention.

Both the ulcer and the adjacent lymph glands were cultured in two cases (89 and 31). The glands in both yielded pure cultures of streptococci: the ulcer in Case 89 gave these together with yeast and sarcinae; in Case 31, the ulcer gave Streptococcus viridans, grampositive and negative bacilli, and staphylococci from the floor of the ulcer, while the emulsion of the wall showed the same streptococcus as the lymph gland, in pure culture. 
Cultures from the material aspirated from the floor of the ulcers were made in ten instances, and from the emulsions of the adjacent normal stomach wall in six. Four of the former and three of the latter proved entirely sterile. In five of the former and in one of the latter, yeast cells and sarcinae were found in large or small numbers. These always grew only under strictly aerobic conditions, especially in the upper one-third of the tubes of dextrose agar. A few colonies of staphylococci were found in six of the cultures from material from the floor of the ulcer, and in one of those from emulsions of the stomach wall, and a few colonies of a large, gram-positive, aerobic bacillus in four of the former. Hemolytic and green-producing streptococci developed in small numbers from the material from the floor of the ulcer in three instances, while from the normal stomach wall streptococci did not develop in a single instance.

Altogether, a more or less thorough search for bacteria in stained sections was made in twenty-seven ulcers of the stomach and twenty ulcers of the duodenum. In fifteen of the gastric and ten of the duodenal ulcers, cultures were made; the rest had been preserved in 10 percent formalin for from two to five years, in the museum of the Mayo Clinic. Sections from all ulcers were stained with hematoxylin and eosin. Diplococci or short chains of streptococci were found in the depths of the wall in twenty-one of the ulcers from the stomach (Figs. 2, 3, 4, and 7) and fifteen of those from the duodenum (Figs. 5 and 6). It was found that the best place to search for the streptococci was near areas of leukocytic infiltration in the subperitoneum and along what appeared to be partition membranes or lymph channels. Yeast cells were found in large numbers in three ulcers in the more or less dense connective tissue and in small numbers in nine others of the ulcers of the stomach and in only three of those of the duodenum. In the one ulcer which showed Staphylococcus aureus in the cultures, gram-staining cocci were found in the depths of the tissue. No bacteria were found in the adjacent normal mucous membrane in any case, and the floor of the ulcer only occasionally showed bacteria in the sections and, except in the ulcers excised after death, the number of these was small, consisting usually of large saprophytic bacilli, yeast cells, and sarcinae. In two of the lymph glands, a few gram-staining diplococci were found in sections, both having yielded streptococci in cultures (Cases 120 and 126); while in one draining a duodenal ulcer of six months' duration (Case 947), the sec- 
tions showed a rather large number of diplococci, and the portion cultured 4,200 colonies of green-producing streptococci in pure culture. Cultures or sections have been made from ulcers or glands draining ulcers, altogether, in fifty-four cases, and gram-staining diplococci or streptococci have been demonstrated in forty-two of these.

A study of the clinical history of the cases of ulcer in conjunction with the sections stained with hematoxylin and eosin and by Gram's method, and the results of the cultures from the lymph glands draining ulcers and of the ulcer wall, show that the number of streptococci is greatest in the relatively acute ulcers and in chronic ulcers in which the clinical history and cellular infiltration indicate a recent lighting up of the infection, and fewest or even absent in the very chronic, markedly indurated ulcers with no clinical microscopic evidence of recent, acute inflammation. Thus, in two cases of gastric ulcer in which yeast colonies were obtained in large numbers, showing their presence, when stained, in the depths of the tissue, in one of which a few streptococci were found and in the other none at all, the ulcers were markedly indurated, sections showed no recent cellular infiltration, and the clinical history no recent increase in symptoms-circumstances suggesting clearly that the ulcers had existed from ten to fifteen years. No such parallelism can be made out in the case of any of the other bacteria.

The results show that the bacterial flora of ulcers excised at operation is very much simpler than that of ulcers excised after death. The number and kinds of bacteria are relatively few, so that, contrary to the view generally held, reliable bacteriologic examination of human gastric and duodenal ulcers can be made if proper methods are employed.

The cultural and other properties of the strains of streptococci isolated, particularly their pathogenicity, are reserved for a later paper. It is sufficient here to state that the strains from twenty-seven cases-all from chronic ulcers-produced small, moist, non-adherent, discrete, grayish-brown or grayish-green colonies on blood (human) agar plates, and produced relatively short chains, and diplococci, and a diffuse turbidity with much acid in dextrose and ascites dextrose broth, and that, when injected into dogs, rabbits, and guinea-pigs, the strains, on isolation, showed a relatively low grade of virulence, but a marked tendency to localize in the mucous membrane of the stomach and duodenum, producing circumscribed areas of infection associated with 
hemorrhage and ulceration in a high percentage of the animals inoculated intravenously; that in three cases-all from relatively acute ulcers -streptococci were isolated which produced typical green colonies and usually long chains in dextrose broth, but also showed marked affinity for the mucous membrane of the stomach or duodenum. The streptococci from the ulcers did not show such preference for relatively anaerobic conditions in ascites dextrose broth as had those from rheumatism. The largest number of colonies were found usually in the upper one half of the tube.

The apparently almost constant occurrence of streptococci in the depths of human ulcer, commonly the more numerous the younger the ulcer and the more marked the cellular infiltration, to the total or almost total exclusion of other bacteria, and the fact that when injected into animals such streptococci show a marked tendency to localize in the stomach or duodenum, a property which other strains of bacteria isolated do not possess, taken in conjunction with clinical facts, constitute good evidence that the streptococci are not merely accidental secondary invaders of the tissues, but are commonly the original cause, as well as the important factor in preventing the healing of the ulcer.

\section{EXPLANATION OF PLATES 4 AND 5 \\ Plate 4}

Fig. 1.-Section of chronic, indurated ulcer of the stomach in a man twenty-seven years of age. Note the connective tissue with little or no cellular infiltration and the marked round cell infiltration around blood vessel. $\times 80$.

Fig. 2.- Streptococci and leukocytic infiltration in peritoneal coat in perforating ulcer of stomach in man. $\times 1200$.

Fig. 3.--Streptococci and leukocytic infiltration in peritoneal coat in acute ulcer of stomach in a woman sixty-two years of age. $\times 1200$.

Fig. 4.-Diplococcus in depths of scar tissue far away from ulcerated surface in an indurated ulcer of lesser "urvature in a man fifty-six years of age. Ulcer present for five years; no exacerbation of symptoms shortly before operation. $\times 1200$.

\section{Plate 5}

Fig. 5.-Streptococci in depths of chronic ( 3 yr.) ulcer of duodenum in a woman fortythree years of age. No history of recent acute attack. $\times 1200$.

Fig. 6.-Streptococci between mucous glands at the base of a chronic (4 yr.) ulcer of duodenum with acute symptoms for ten weeks before operation. $\times 1200$.

Fig. 7.-Streptococci and leukocytic infiltration in chronic ulcer with acute exacerbation shortly before operation. $\times 1200$.

Fig. 8.-Diplococci in peritoneal ccat of ulcer of the duodenum (see Case 112 in Table 1). 


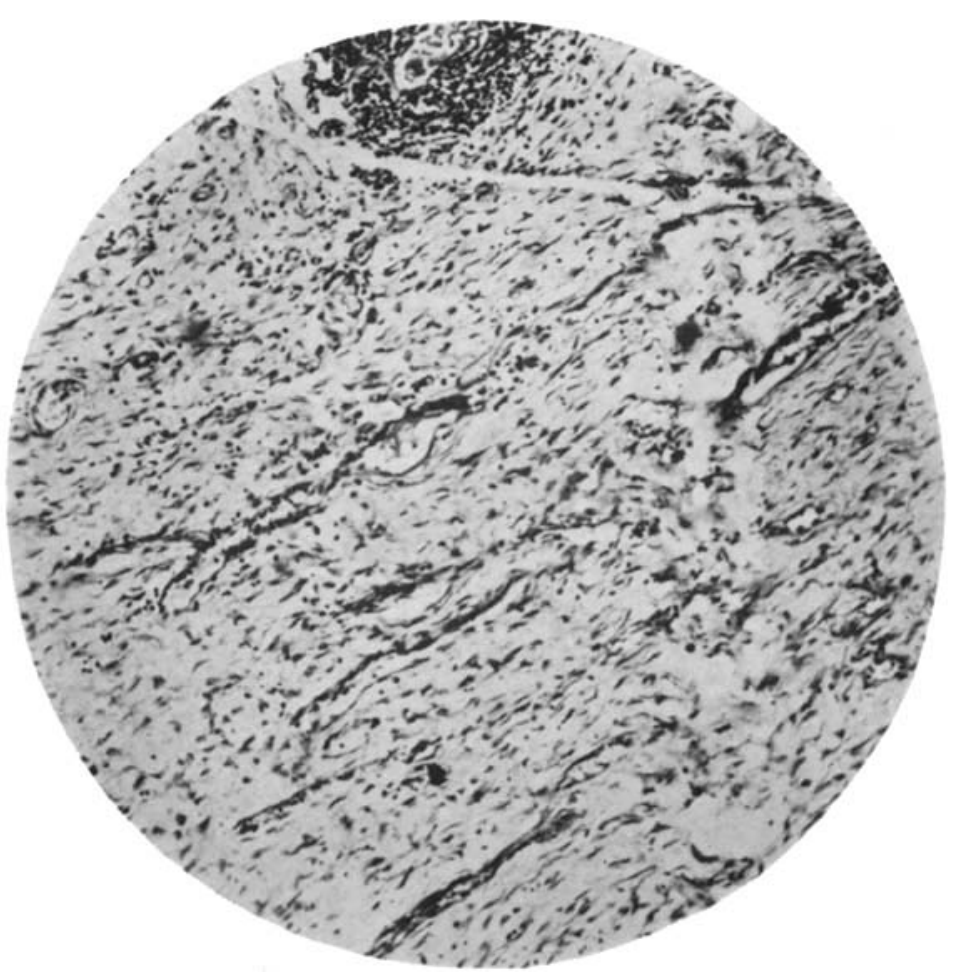

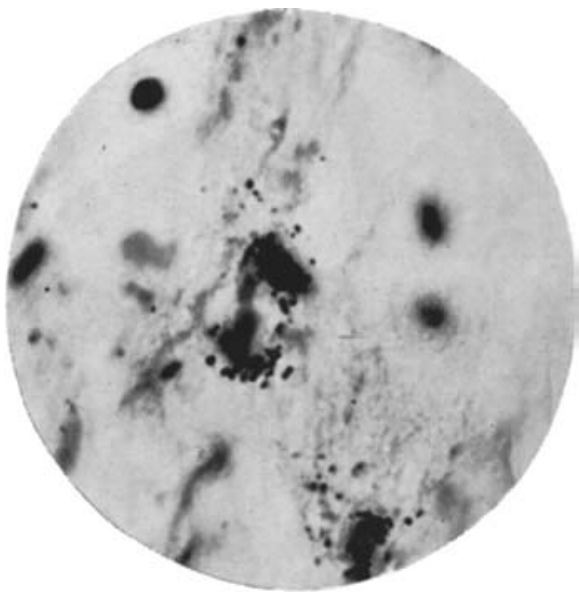

Fig. 2

Fig. 1
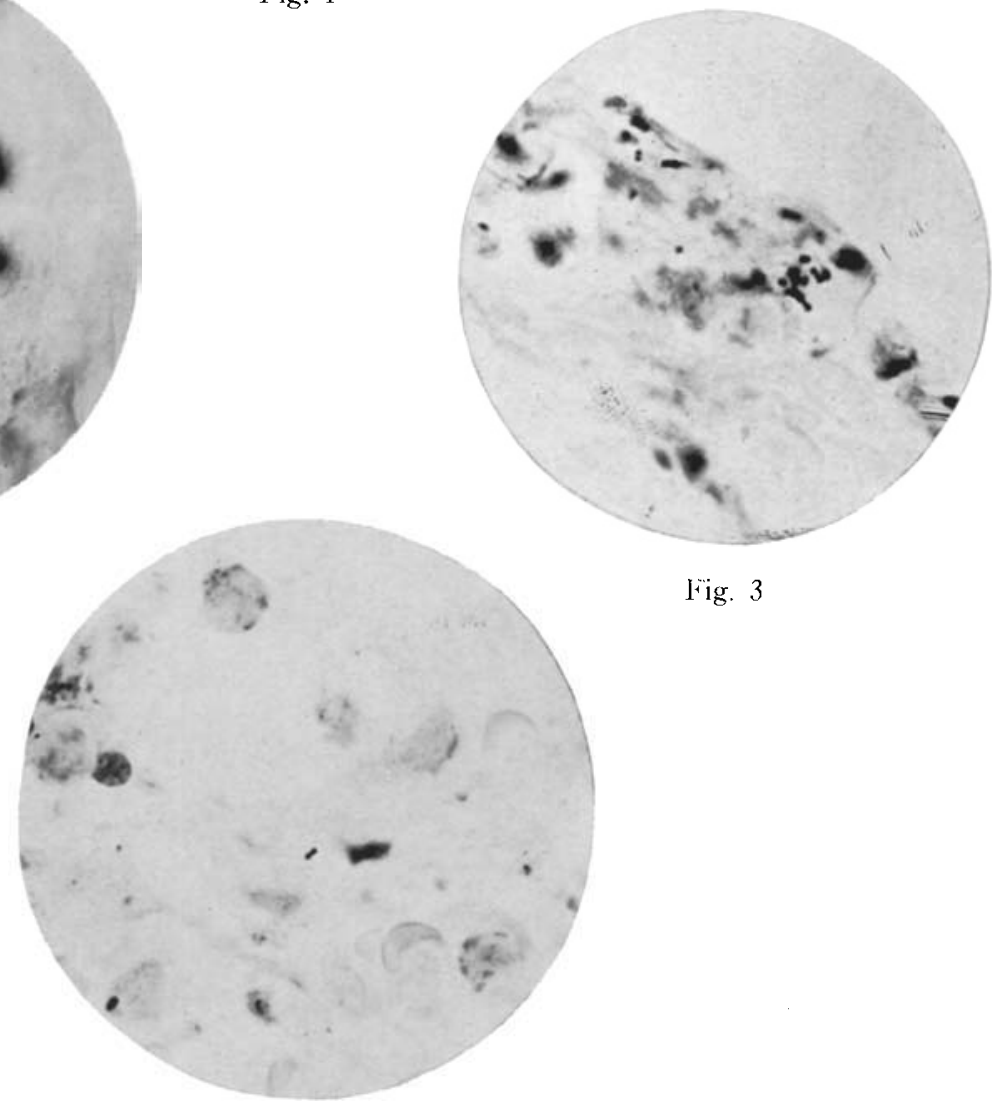

Fïg. 3 
Plate 5

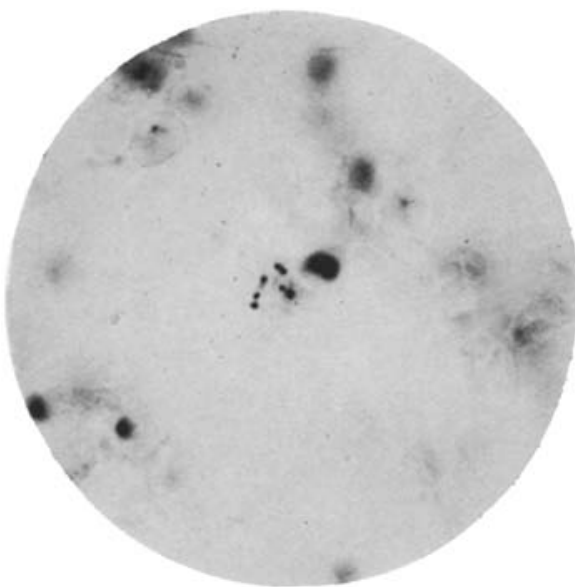

Fig. 5

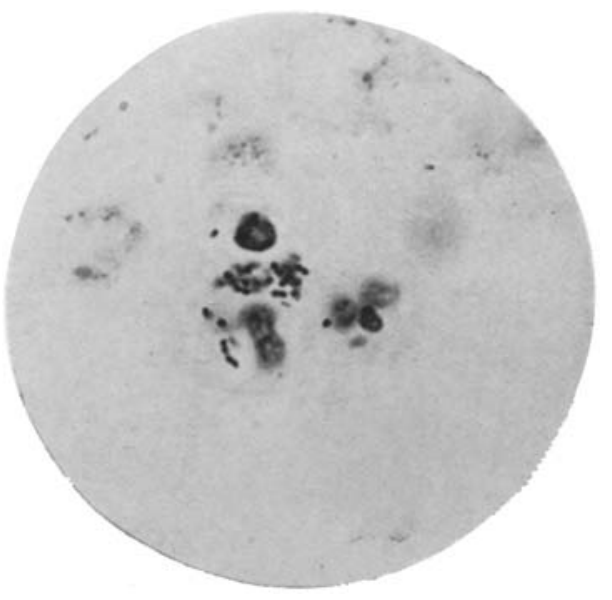

Fig. 7

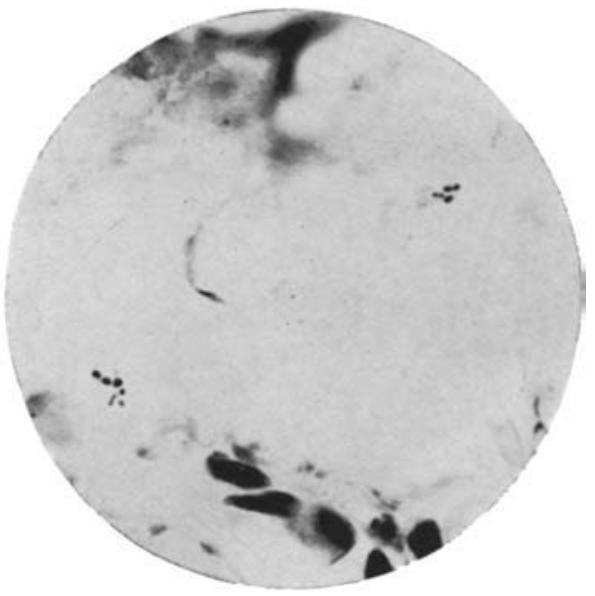

Fig. 6

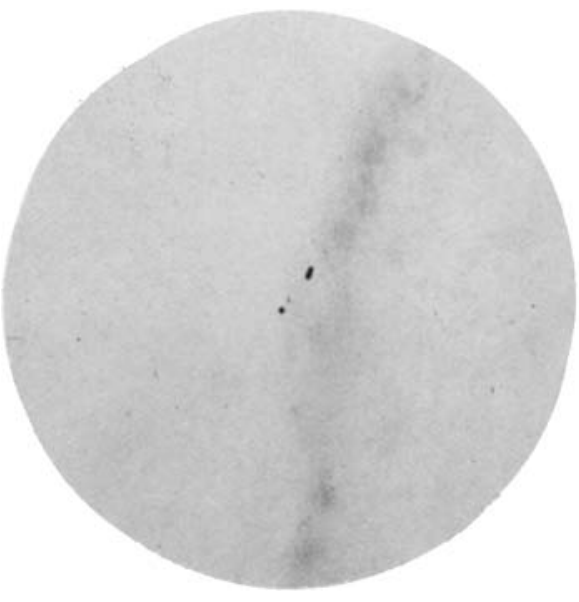

Fig. 8 